\title{
CURADORIAS COMPARTILHADAS EM EXPOSIÇÕES INDÍGENAS: O CASO DE "DJA GUATA PORÃ" NO MUSEU DE ARTE DO RIO
}

LEANDRO GUEDES ${ }^{1}$

UNIRIO, BRASIL

JOSÉ RIBAMAR BESSA ${ }^{2}$

UNIRIO, BRASIL

RESUMO: $O$ artigo tem por objetivo discutir a curadoria compartilhada de indígenas na construção da exposição "Dja Guata Porã: Rio de Janeiro Indígena", realizada no Museu de Arte do Rio (MAR) entre os meses de maio de 2017 e março de 2018. Seus autores participaram da exposição na qualidade de pesquisador e curador, respectivamente, acompanhando os processos aqui narrados, as reuniões e os encontros da equipe, formada por técnicos do MAR e convidados externos, dentre os quais representantes qualificados de diferentes etnias, que vivenciaram as distintas etapas de construção da exposição. Puderam assim observar como se articularam as relações interculturais estabelecidas no processo de elaboração da referida mostra e as interlocuções diretas com os indígenas, situando-as aqui de forma sucinta no contexto das propostas sobre as estruturas do trabalho museológico da denominada "Nova Museologia".

PALAVRAS-CHAVE: Curadoria compartilhada. Museus de arte. Nova Museologia. Povos indigenas. Interculturalidade.

ABSTRACT: The article intends to discuss the shared curatorship with indigenous people in the exhibition "Dja Guata Porã: Rio de Janeiro Indigena", held at the Museu de Arte do RIO (MAR) between May 2017 and March 2018. Its authors participated in the exhibition as researcher and curator, respectively, following all the exhibition creation processes, reunions with the MAR professionals and external guests, including qualified representatives of different indigenous groups, who experienced the different stages of the exhibition creation. They were able to observe how the intercultural relations established in the elaboration process of this exhibition and the direct conversations with the indigenous people were articulated, placing them in the context of the proposals on the structures of the museological work of the so-called "New Museology".

KEYWORDS: Shared curatorship. Art museums. New Museology. Indigenous people. Interculturality.

\footnotetext{
${ }^{1}$ Mestrando do Programa de Pós-graduação em Museologia e Patrimônio (PPG-PMUS) UniRio/MAST. Email: leandroguedes84@gmail.com

${ }^{2}$ Professor da Pós-Graduação em Memória Social da Universidade Federal do Estado do Rio de Janeiro (UNI-Rio). Coordena o Programa de Estudos dos Povos Indígenas (PROÍNDIO/UERJ) e o Laboratório de Pesquisas em Oralidade (Laboral/UNIRIO). E-mail: jrbfreire@yahoo.com.br
} 


\section{Introdução}

Em meados de outubro de 2016 o Museu de Arte do Rio (MAR) começa a preparar uma nova exposição de longa duração para substituir "Leopoldina, princesa da Independência, das artes e das ciências", que ocupava o terceiro andar do pavilhão de exposições do prédio do Museu localizado na Praça Mauá, Centro do Rio, dedicado à história do Rio de Janeiro.

Pela primeira vez o MAR propôs-se a realizar uma exposição inteiramente dedicada aos povos indígenas, que antes apareciam somente como temas transversais, pano de fundo de outras narrativas. Inaugurada em maio de 2017, "Dja Guata Porã: Rio de Janeiro Indígena" teve a curadoria conjunta de Clarissa Diniz, Sandra Benites, Pablo Lafuente e José Ribamar Bessa Freire.

Os autores deste texto tomaram parte na exposição "Dja Guata Porã: Rio de Janeiro Indígena" nos papéis de pesquisador e curador, respectivamente. No presente artigo nos propomos a apresentar e debater o processo de concepção da exposição e de que maneira os diversos povos indígenas foram se inserindo neste processo, a partir das observações vivenciadas em campo, durante a construção da referida mostra.

Esta exposição, imaginada primeiramente com outro nome, também não trazia consigo muitas decisões sobre seu formato, que dificilmente foi imaginada do modo que foi construída; apenas que seria uma mostra dedicada à presença indígena na cidade do Rio de Janeiro, com uma linguagem que fosse contemporânea, que fugisse das representações equivocadas sobre os povos indígenas, comumente retratados como personagens "atrasados" e "genéricos" (e por vezes caricaturais), ignorando-se os mais de 300 povos indígenas que habitam o território nacional, dotados de línguas e culturas próprias e diferentes entre si.

Os museus, sabemos, apresentam distintas configurações, seja no esforço decolonial de combate a preconceitos culturais e como ferramenta a ser apropriada por atores historicamente silenciados e apagados, seja na perpetuação de uma identidade colonialista, monolítica, fundamentada na interpretação que consolida a narrativa de uma epopeia eurocentrada de "conquista" do Novo Mundo. Este esforço decolonial em desenvolver uma exposição com grupos que não participam habitualmente dos espaços museais, evidencia a potência dos museus como espaço de "fronteira dialética" entre atores hegemônicos e subalternizados. A ideia de construir algo novo, para ser comunicado coletivamente, transforma os museus em "zonas de contato" de transações interculturais, possibilitando subverter as lógicas de dominação científico-políticas (CLIFFORD, 2003) de exposições e do colecionismo em museus. 


\title{
Dja Guata Porã: um processo curatorial participativo
}

A equipe curatorial criou o projeto de exposição inicialmente chamado "Guanabara antes dos Cariocas". Tomaram parte deste processo como curadores em um primeiro momento, a convite de Clarissa Diniz, gerente de conteúdo e curadora do MAR, o curador espanhol Pablo Lafuente e o professor José Ribamar Bessa Freire. Partiu de Bessa Freire a ideia de convidar a indígena Sandra Benites para integrar a equipe de curadores da exposição, privilegiando outros saberes e outros olhares que se mostraram decisivos para o resultado final do projeto. Uma equipe de pesquisa, também articulada pelo professor José Bessa, foi formada por Ana Paula Silva, Ignacio Gomez, Mariane Vieira e Leandro Guedes. Como destaca a museóloga Mariane Vieira, a curadora Clarissa Diniz encarou a curadoria da exposição como obra coletiva, evidenciando o caráter processual de sua construção no seu discurso de inauguração:

\begin{abstract}
Esta exposição não foi curada por nós [os curadores], mas num gesto curatorial eminentemente de mediação, de interlocução, de escuta e de diálogo, que foi gerando isso aqui, quase como partes que vão se encontrando [...] numa força que de fato foi coletiva. [...] Nenhum de nós, durante vários meses, sequer imaginávamos como a exposição seria, nos primeiros meses fizemos muitos encontros aqui no museu, fora do museu [...] Tudo que aqui está surgiu destas conversas. (VIEIRA, 2019, p.233)
\end{abstract}

Sem a coordenação de Clarissa Diniz, a exposição não teria assumido tais procedimentos. A metodologia adotada foi a de buscar um diálogo direto com as aldeias Guarani e Pataxó do RJ e com alguns grupos indígenas da cidade. Foram realizados encontros abertos e reuniões dentro do museu com representantes destes grupos indígenas, assim como dentro das próprias aldeias. Como destaca Vieira (idem), esta etapa do trabalho consistia na aproximação de diálogo em que apresentávamos a proposta da exposição, convidando-os a visitar o MAR e havendo interesse - houve sempre - este contato era mantido através de reuniões periódicas, marcadas de acordo com a disponibilidade dos grupos envolvidos. As reuniões tinham por objetivo definir de que maneira cada grupo indígena participaria na exposição e através de quais meios e suportes gostariam de elaborar suas narrativas. Tais atividades foram subsidiadas pelo MAR, na lógica que o museu já operava anteriormente com os artistas que ali expuseram, de obras comissionadas, garantindo o direito de propriedade intelectual dos produtores, podendo ou não serem incorporados ao acervo.

A prática do MAR equiparou os indígenas aos demais expositores, abriu a possibilidade de retirá-los do exílio simbólico ao qual foram relegados e valorizou suas produções, contextualizando suas realidades atuais através de vídeos, fotografias e objetos, o que permitiu combater a estereotipagem e a violência simbólica que ocorrem em locais onde há 
desigualdades de poder (HALL, 2016). Com o convite aos indígenas para construírem suas autonarrativas, o MAR criou uma participação real nos processos decisórios, especialmente no que diz respeito à comunicação museológica, dentro dos limites razoáveis previstos em orçamento. Como lembra Roca (2015, p.143) é comum que em práticas colaborativas as relações sejam em algum momento assimétricas, sempre havendo "quem possa falar mais alto". Contornar este problema só é possível quando a lógica do museu se modifica, servindo, por assim dizer, como "prestador de serviço" dos indígenas, ou seja, colocando à disposição deles meios para que suas histórias possam ser contadas, em diálogo, sempre que necessário e solicitado, com pesquisadores e especialistas que atuam como mediadores para que estas realidades sejam comunicadas ao visitante.

Embora inovadora no MAR, as práticas colaborativas em museus não são novidade e vêm merecendo reflexões nesse campo do saber. $O$ movimento museológico denominado Nova Museologia, oficializado na Declaração de Québec, no Canadá, em 1984, e começado com a criação dos chamados ecomuseus na França nos anos 1970, enfatizou o papel que o museu deve desempenhar socialmente, através de novas teorias e práticas. Segundo Suzy Santos (2017), o termo foi criado por André Desvallés e popularizado por Hugues de Varine. Um dos autores mais críticos sobre o movimento, o canadense René Rivard, adota uma postura mais crítica e menos romanceada pelos ideais franceses iluministas de seus colegas francófonos, distanciando-se da primeira proposta de Desvallés.

Para Rivard a Nova Museologia tem como proposta expandir os conceitos de edifício, coleção, público e especialistas trabalhados no museu tradicional. [...] enfatiza a importância da coletividade, em sua opinião o principal elemento das ações geradas por este movimento museológico (SANTOS, 2017, p. 59).

Embora a "Nova Museologia", organizada a partir do contexto francês na década de 1980, não seja um termo consensual nesta área de estudos, o termo passou, no entanto, a ser entendido como um movimento ou uma "nova" museologia de fato, que representa uma mudança de paradigma, uma ruptura com uma "museologia tradicional" no campo museológico, e passa a refletir a junção de teorias e práticas que envolvem a socialização das relações de poder e autoridade com grupos relacionados ao território, a coleções ou na criação de exposições. Para Peter van Mensch (1994), a chamada "Nova Museologia" diz respeito a uma verdadeira revolução, que modifica as estruturas do trabalho museológico - e das instituições museais - com um museu mais integrado à sociedade e ao desenvolvimento comunitário. A corrente teórico-prática chamada de "Museologia Experimental", que também evoca ideias da "Nova Museologia" ou "Museologia Social", vai privilegiar em suas análises uma "museologia comprometida e aberta aos diferentes regimes de valor" (BRULON, 2019, p. 201) de experiências museais não institucionalizadas. 
Tais análises se dariam sobre a observação das experiências individuais ou coletivas em dado espaço socialmente constituído, e da análise dos diferentes atores sociais envolvidos nos processos de musealização, e na produção de valores museais comunitários.

Podemos destacar as práticas do Museu do Índio, ligado à Fundação Nacional do Índio (FUNAl), no Rio de Janeiro, que desde o início dos anos 2000 envolve os indígenas em praticamente todas as suas atividades, seja na elaboração e montagem de exposições, seja em projetos de pesquisa. Sua primeira exposição neste formato foi "Tempo e Espaço na Amazônia: Os Wajãpi”, com curadoria da antropóloga Dominique Gallois. Mesmo o Museu não tendo legitimidade para falar pelos indígenas, uma vez inseridos como produtores da exposição em parceria com os antropólogos, ambos agem como criadores de referências culturais e constituem-se atores no processo de produção das interpretações dos indígenas enquanto sujeitos museológicos. A montagem da exposição se deu a partir da produção de objetos pelos Wajãpi, com a participação efetiva de todas as 13 aldeias do Amapá que participaram da mostra. Foram mais de 300 objetos produzidos. De acordo com a curadora, "foi a primeira vez que um grupo indígena da Amazônia participou tão intensamente e, sobretudo, coletivamente, da preparação de uma exposição." (ABREU, 2007, p.170).

O diálogo intercultural estabelecido permitiu que os Wajãpi produzissem suas próprias narrativas, obedecendo seus costumes e valores estéticos. Neste sentido a antropóloga Regina Abreu (2007) assinala dois momentos interessantes na montagem da exposição. Primeiro os Wajãpi proíbem a exibição de imagens de pessoas que já tivessem falecido, pois isto seria prejudicial aos espíritos. Em outra ocasião, quando varas compridas foram posicionadas para dar "sustentação ao céu", as mulheres Wajãpi ordenaram a pintura de um grande círculo vermelho ao redor das varas, pois sem o círculo nada adiantaria a instalação das varas para "conter o mundo de cima". Podemos citar como um impacto direto e importante para o Museu do Índio, o fato de ter possibilitado a criação de um acervo totalmente qualificado na sua documentação museológica. Uma vez que a seleção e aquisição de objetos deixa de ser coletada em campo, mas através de uma demanda específica, o conhecimento indígena sobre os objetos torna-se indispensável para sua musealização, pois as coleções adquiridas diretamente com as etnias envolvidas vêm com todas as informações relacionadas aos objetos, tais como matéria-prima, função e o artesão que o produziu. (COUTO, 2012; BRULON e GUEDES, 2019).

Outras práticas que merecem ser citadas são as desenvolvidas pelo Museu de Arqueologia e Etnologia da Universidade de São Paulo (MAE/USP), assim como pelo Museu Histórico Pedagógico Índia Vanuíre no Oeste Paulista, que também mantém o Centro de Referência Kaingang, onde, de acordo com a museóloga Marilia Cury (2016), funciona uma espécie de "laboratório de experimentações museológicas", estimulando o debate e a participação indígena nas exposições e demais atividades desenvolvidas pelo museu. 
Organizadas pelos próprios indígenas, outras práticas contrahegemônicas merecem destaque, tais como o Museu Magüta e o Museu Kuahi na região amazônica (Amazonas e Amapá, respectivamente) e os diversos museus indígenas que tem sido criados em todo o Nordeste, seguindo o exemplo do Museu Kanindé fundando em 1995 pelo cacique Sotero, no município de Aratuba, Ceará. Além de cinco museus criados em aldeias do Oeste Paulista para valorizar suas línguas e culturas: Museu Worikg Kaingang e Museu Akãm Orãm Krenak, ambos na T.I. Vanuire, Museu Nhandé Manduá Rupá na Aldeia Nimuendaju, Museu Ekeruá Terena na T.I. Araribá e Museu de Icatu Kaingang e Terena. No mapeamento realizado por Santos (2017, pp. 199 a 212), ela apresenta uma lista de 196 museus comunitários ou ecomuseus no Brasil, com o ano de criação de cada um, sua localização e a comunidade onde atua.

A necessidade de diálogo e de uma melhor integração com os nãoindígenas que vivem ao redor, e a afirmação identitária são algumas das motivações por trás da criação destes museus comunitários. A experiência do museu Maguita é um bom exemplo neste sentido, pois funcionou como mediador de um grave conflito entre os Ticuna, de um lado, e madeireiros e seringalistas, de outro. Não foi um caminho fácil, pois a população não-indígena no município de Benjamin Constant no Amazonas inicialmente simpatizou e tomou partido, enfileirando-se ao lado de latifundiários e madeireiros, incluindo o prefeito do município. A aproximação entre os Ticuna e o restante da população local foi alcançada graças ao Museu, que auxiliou no combate às ideias discriminatórias em relação aos indígenas e no consequente apaziguamento, ainda que temporário, na região em conflito (BESSA FREIRE, 2003; ROCA, 2015).

O antropólogo José Reginaldo Gonçalves (2007) entende os museus como espaços do sistema arte-cultura tal como proposto por James Clifford (2003), numa perspectiva das teorias antropológicas sobre a construção e percepção do "outro". Ele analisa como os chamados "profissionais de museu" lidam com a alteridade e chama atenção de como "grupos e categorias sociais representam e constituem simbolicamente suas inter-relações e sua inserção na sociedade brasileira" (GONÇALVES, 2007, p.86). Gonçalves destaca, ainda, em outra passagem, que comumente não nos damos conta das relações que se estabelecem em um museu, tanto no seu funcionamento interno, como para uma exposição ser viabilizada e realizada, percorrendo-se uma "complexa e extensa cadeia de ações sociais e simbólicas" (idem, p. 82).

\section{Os encontros de curadoria}

Tais relações complexas foram evidenciadas nas reuniões e nos encontros abertos promovidos pelo MAR para pensar a exposição, denominados com o nome guarani de "Dja Guata Porã" ("caminhar bem e caminhar junto" em tradução livre), surgido da fala da curadora Sandra Benites, que mais tarde deu nome à exposição. Os encontros Dja Guatá Porã contaram com a participação, principalmente, de pesquisadores indígenas e não-indígenas, de profissionais de museu e de indígenas 
ligados a movimentos sociais, assim como de funcionários do MAR. Os "Dja Guata Porã" foram organizados em quatro ocasiões, ocorrendo paralelamente às reuniões semanais que a equipe curatorial e de pesquisa realizava no museu, buscando delinear a exposição. Funcionava como um fórum de ideias, no qual indígenas e não-indígenas puderam trocar suas impressões, vivências e expectativas sobre uma exposição que viria retratar a presença dos povos indígenas no Rio de Janeiro.

Nestes encontros podemos destacar algumas passagens das reuniões como as falas de Carlos Tukano, de Edson Kayapó e de Josué Kaingang, importantes pelo direcionamento que deram à Exposição e pelos debates que provocaram.

Carlos Tukano, 59 anos, nasceu no rio Tiquié, no Rio Negro (AM), mas vive há mais de 20 anos no Rio, onde acabou sendo eleito "cacique" da Associação Indígena Aldeia Maracanã (AIAM) e presidente do Conselho Estadual dos Direitos Indígenas (CEDIND) do Rio de Janeiro. É reconhecido nacionalmente pelo movimento indígena. Na primeira reunião aberta em 04 de novembro de 2016, com seu cocar de penas amarelas e alaranjadas, ele destacou a necessidade de que a exposição focasse o indígena contemporâneo do séc. XXI e não o indígena do passado descrito na carta de Pero Vaz de Caminha de 1500. De acordo com a fala do cacique Tukano, muitos "brancos gostam de ver o índio como um animal no zoológico", cabendo ao museu contribuir para "desfazer a imagem do indígena como atrasado e engessado no tempo, ou como inimigo do progresso". Ainda de acordo com Carlos Tukano, com a exposição o "índio tem a oportunidade de mostrar sua realidade concreta. $O$ índio tem que sair da vitrine".

Neste sentido, a museóloga Tereza Scheiner (1999) nos diz que as percepções do real nos museus correm o risco de criar uma realidade de discursos fragmentados que, se retirados do seu contexto original, não permitem perceber uma outra realidade, diversa em sua totalidade, construindo uma imagem distorcida do "outro". Este controle de narrativas que "mostra um falso pluralismo" (idem, p.148), manipulado por discursos hegemônicos, ainda está presente em certa medida em museus etnográficos, museus nacionais e de belas artes.

Para Vidal (2000, p.280), ao retratar as criações artísticas dos índios deve-se "levar em conta os contextos socioculturais dos povos a que se pretende observar, enquanto elementos de teorias cosmo-sociológicas nativas, que ordenam e dão sentido ao mundo". Em nosso entendimento isto deve ser estendido a quaisquer produções indígenas exibidas em museus. A dificuldade reside exatamente neste último item, levando em consideração que as produções artísticas destas culturas ainda são exotizadas, subalternizadas. São colocadas nos "degraus hierárquicos" mais baixos do que é considerado como item de valor de mercado na definição ocidental.

Edson Kayapó, 46 anos, outro participante dos encontros no MAR, é coordenador do Curso de Licenciatura Intercultural Indígena do Instituto Federal da Bahia. Mestre e Doutor em História Social pela PUC/SP, ele destacou a necessidade "de produzir uma exposição ligada às tradições ameríndias", com o museu dando audibilidade e visibilidade aos 
indígenas, para garantir que sejam protagonistas ao contarem suas próprias histórias, colaborando para retirá-los da invisibilidade histórica, privilegiando suas produções. Enfatizou, ainda, que os indígenas hoje dominam a tecnologia do "branco" como instrumento de resistência. Manipulando estas ferramentas, como as mídias sociais e a produção de vídeos, para dialogar com a sociedade não-indígena, luta por direitos e na salvaguarda de sua própria cultura. Outros aspectos práticos do cotidiano e da arte indígena foram trazidos para debate: a necessidade da produção de sua arte para venda, questão identificada como sensível por todos os envolvidos na elaboração da exposição, e como ela se transforma na maioria dos casos na principal fonte de renda destes povos.

Este tema também foi abordado no segundo encontro com 0 pesquisador Josué Carvalho Kaingang, 36 anos, da Terra Indígena Nonoai (RS), ex-professor da Escola Indígena Perõga, mestre em Memória Social (UNIRIO) com dissertação sobre a infância Kaingang e doutor em Educação (UFMG) com tese sobre as narrativas dos velhos. No encontro do MAR, ele discorreu sobre as três dimensões da produção de objetos pelos povos indígenas: uso ritual e religioso, uso doméstico e cotidiano e destino comercial para venda. Alguns questionamentos de Josué auxiliaram a nortear o trabalho da equipe curatorial e de pesquisa no que diz respeito à cultura material indígena. Ele formulou algumas questões, dentre as quais duas merecem registro: Tudo o que o indígena produz pode e deve ser musealizado? Como o museu lida com os objetos que os indígenas entendem como sagrado?

Evitando repetir modelos tradicionais de uma exposição de arte indígena, o projeto expositivo começava a nascer com a ambição de tornar-se uma exposição transversal, entrecruzando perspectivas históricas de silenciamento, apagamento e questões contemporâneas. Buscava assim rejeitar o monolinguíssimo colonizador e procurava questionar a valoração de suas produções somente pelo viés estético, incluindo-as na categoria de "etnoarte" ou "arte primitiva", em uso por diversos museus etnográficos europeus, comprometidos com a lógica do mercado de arte. O propósito era o de seguir os direcionamentos expostos sobretudo pelos indígenas nos "Dja Guata Porã" e nas reuniões, privilegiando as discussões sobre a contemporaneidade da presença indígena, os silenciamentos e apagamentos históricos, reunindo um conjunto plural de objetos, documentações, experiências, dando atenção especial às dimensões políticas, ressaltando processos de resistência e de relações interculturais, de troca ou dominação, que fossem expostos não obedecendo o paradigma do "cubo branco"3 em toda a sua totalidade. Recurso comum em museus de arte, cuja proposta comunicacional "supervaloriza a formalidade e rigidez das obras expostas" (MORAES, 2014, p. 220), em salas com paredes e suportes de fundos neutros,

\footnotetext{
${ }^{3} \mathrm{O}$ conceito de "cubo branco" teve origem em estudos empreendidos pelo movimento modernista da escola de design e arquitetura alemã Bauhaus e sua experiência mais famosa e emblemática é a do Museum of Modern Art (MoMa), de Nova York. (MORAES, 2014. O’DOHERTY, 2002).
} 
invariavelmente pintadas de branco, desenhadas para favorecer uma melhor percepção visual dos visitantes sobre as obras expostas.

Em sua concepção museológica, a comunicação é o processo pelo qual uma coleção adquire sentido, tornando-se acessível e tendo seu valor científico, cultural e educacional transmitido a um público. Para Stránský (1974, p. 31 ), a comunicação é a abordagem museológica da realidade, criadora de uma conexão recíproca com a realidade original que é estabelecida em "um nível qualitativamente elevado". A autenticidade viva investida nas produções indígenas afasta-se da ideia de que objetos materiais em museus etnográficos (ou, ainda, de outras tipologias) são vestígios de uma cultura que está extinta ou prestes a desaparecer, de modo que esses objetos podem ser percebidos como patrimônios interculturais vivos, essenciais para a sobrevivência dos produtores autônomos no presente e para sua afirmação política além da vitrine de um museu (STOCKING JR. 1985; BRULON e GUEDES, 2019).

\section{Os indígenas contemporâneos do Rio de Janeiro}

Uma linha do tempo da presença indígena no Rio de Janeiro foi construída pela historiadora Ana Paula Silva, com base em sua tese de doutorado orientada por José Bessa, que discute, entre outras questões, a presença dos indígenas em contexto urbano no Rio de Janeiro do século XIX. A linha do tempo funcionou como norteadora de fatos e acontecimentos para que pudessem ser devidamente analisados, e posteriormente operassem como uma base na montagem da exposição.

A presença dos indígenas no território fluminense é alguns milênios anterior à chegada dos europeus, conforme evidências arqueológicas. Posteriormente, numa perspectiva da documentação histórica escrita, destacam-se as alianças estabelecidas entre, de um lado, Tupinambá e franceses e, de outro, portugueses e Tupinikin, num processo bastante complexo das intrincadas relações interétnicas. A criação dos aldeamentos indígenas do século XVI do que hoje conhecemos como território do Rio de Janeiro deu origem a processos violentos promovidos pelos portugueses de dizimação dos povos, do uso dos indígenas como força de trabalho escravo, de recrutamento da força de trabalho através dos descimentos, guerras justas e "resgates", além da política de assimilação pela catequização forçada que ao longo dos séculos colaborou com o desaparecimento de línguas e saberes milenares e do abandono de costumes tradicionais e das construções das aldeias de repartição e usurpações das terras indígenas.

A questão dos apagamentos e silenciamentos, como mencionado anteriormente, foi um tema que a equipe decidiu abordar, com anuência dos indígenas que participaram dos debates, dialogando com a realidade atual de índios em contexto urbano, tendo o Rio de Janeiro como uma "zona de contato cosmopolita" entre os povos indígenas desde os primeiros aldeamentos até o papel desempenhado por eles a partir do século XIX, quando criaram, como mecanismo de defesa, diversas 
estratégias de interações com o colonizador, a partir da assimilação dos conhecimentos incorporados na convivência urbana (PRATT, 1999).

Estas presenças indígenas nas cidades e as relações interétnicas contemporâneas foram trazidas para a conversa pela curadora Clarissa Diniz, reforçada por Sandra Benites que, embora tenha suas aldeias de referência em Mato Grosso do Sul e no Espírito Santo, vive em contexto urbano, na chamada Aldeia Vertical, nome dado à moradia de famílias indígenas após a expulsão destas da ocupação do antigo prédio do Museu do Índio no bairro Maracanã, em 2013.

Cabe ressaltar aqui a atuação de Sandra Benites como curadora e articuladora na exposição "Dja Guata Porã: Rio de Janeiro Indígena". Convidada pelo professor José Bessa para integrar a curadoria, foi a principal responsável por conduzir os debates de acordo com a perspectiva indígena, ora trazendo temas importantes e sensíveis a todos os povos (em especial sobre a questão territorial e de demarcação de terras, o preconceito e as dificuldades da vida em aldeia), ora ressaltando universos ligados à sua vivência e história enquanto mulher guarani, professora, que viveu tanto em aldeia, quanto em ambientes urbanos. Sandra Benites, mestre em antropologia pelo Programa de Pós-Graduação da UFRJ/Museu Nacional, transita "entre dois mundos" e sua participação como curadora foi fundamental na costura de um tecido intercultural de diálogos e acordos entre todos os grupos indígenas que participaram da exposição, sobretudo com as aldeias Guarani do Rio de Janeiro e com os grupos da Aldeia Vertical, incluindo-se os grupos Puri, uma vez que alguns indígenas desta etnia lá residem.

A Aldeia Vertical é uma aldeia urbana multiétnica, organizada na AIAM - Associação Indígena Aldeia Maracanã -, representada pelo cacique Carlos Tukano. Lá residem aproximadamente pessoas de 17 etnias, alguns nascidos em aldeias, outros que já nasceram e vivem na cidade. A AIAM instalou-se neste prédio após negociações e reivindicações junto ao governo do Estado do Rio de Janeiro, que os expulsou de maneira violenta do antigo prédio do Museu do Índio nas ocupações de 2012 e 2013 contra a demolição do prédio, realocando-os inicialmente em contêineres no leprosário de Curupaiti no bairro de Jacarepaguá. Esta situação foi totalmente insalubre e desconfortável para os indígenas, colocados em um ponto distante da cidade, de difícil locomoção para outros bairros, em locais quentes e sem ventilação adequada para dizer o mínimo.

Após inúmeras negociações e reivindicações junto ao governo estadual, foram alocados no atual endereço, em um bloco do "Minha Casa, Minha Vida", programa do governo federal em parceria com o governo estadual de moradias populares no bairro do Estácio. Sobre a ocupação no espaço urbano a curadora Sandra Benites comenta que

A Aldeia Maracanã é importante porque é onde a gente constrói, apesar da diversidade, mas, pelo menos, a gente vive um pouco em nossa condição de indígena [...] Eu me sentia muito bem lá, eu me sentia acolhida. [...] 
Eu via a casa caindo aos pedaços, mas eles estavam muito felizes ali [...] só que agora, depois que a gente mudou ali na Aldeia Vertical, é uma tristeza enorme que tomou conta da gente. Eu acho que se perdeu essa essência indígena ali [...] [Aldeia Vertical] foi apenas priorizada, porque os indígenas da Aldeia Maracanã foram despejados lá no Curupaiti [...] É um prédio, cada um no seu canto [...] você não tem como dividir as coisas ali. (VIEIRA, 2019, p.244-245).

Os indígenas que ocupavam o prédio do Museu do Índio no Maracanã constituem um grupo com divisões e conflitos internos, seja em estratégias políticas, seja no que diz respeito à forma de ocupação do antigo Museu do Índio e seu uso futuro. Ali, os movimentos indígenas não constituem um bloco homogêneo, tendo dois principais núcleos: a já mencionada Associação Indígena Aldeia Maracanã e o grupo Aldeia Rexiste, liderado por José Guajajara. O MAR acolheu os dois grupos. Como recorda a pesquisadora Mariane Vieira, o panorama de ocupação é bastante complexo "pois inclui indígenas que vieram de suas aldeias e outros que já nasceram no contexto urbano". Em seu artigo intitulado "Dja Guata Porã: O rio indígena que desaguou no MAR", Vieira (2019) evidencia estes problemas nas falas de José Guajajara sobre o movimento.

Por volta da década de 90, procurava os parentes no Rio de Janeiro, não encontrava. Mas me falaram que tinha um espaço, antigo Museu do Índio, no Maracanã e era o espaço que nós procurávamos para discutir políticas públicas para os povos originários. [...] Então, por volta de 2004, nós fizemos a primeira tentativa, não foi registrado [...] Só em 2006, nós conseguimos reunir [...] por volta de 20 etnias do território nacional [...] Então, começa aí a história de um espaço que talvez nos representaria. [...]. (idem, p.244)

Outro indígena que esteve presente no movimento desde o início, Afonso Apurinã, também é destacado por Vieira

Eu acho que nos últimos anos foi uma história das mais importantes, [...] ali foi um espaço criado para defender os povos indígenas. [...] $O$ povo daquela região [Maracanã] veio ressurgir através da gente. [...] Eu trouxe um álbum [de fotografias] que a gente pode estar mostrando nessa exposição. (ibidem, p. 246)

Outras presenças também se efetivaram. Dois povos foram trazidos como pontos de partida no diálogo entre passado e presente: os Guarani e os Puri. No livro "Aldeamentos Indígenas no Rio de Janeiro" (2009), o professor José Bessa explica que na verdade o nome Puri é uma forma pejorativa dada pelos Coroado, com quem viviam em guerra. Por falta de documentação da época que revelasse o verdadeiro nome deste povo, 
esta acabou sendo sua identidade definitiva. Seu contato com os colonizadores foi tardio em relação a outros indígenas; referências sobre os Puri são achadas em documentos somente no século XVIII, sendo alguns grupos contatados apenas durante o século XIX. Se o contato foi tardio, a dizimação aconteceu de forma rápida: os Puri foram dados como extintos no início do século $X X$, e atualmente encontram-se em importante processo de etnogênese.

A convite do curador José Bessa, alguns índios Puri e o historiador Marcelo Lemos compareceram a reuniões e participaram do processo de construção da exposição, manifestando aos curadores e pesquisadores que os Puri existem e resistem em um vigoroso movimento de ressurgência étnica. Em seu livro "O índio virou pó de Café?" (2016), Lemos discute o processo violento de extermínio dos indígenas do Vale do Paraíba, que foram dizimados pelos barões do café, e os que sobreviveram, tiveram suas identidades indígenas suprimidas ou camufladas, muitas vezes por iniciativa própria, como estratégia de sobrevivência. Durante seu trabalho de pesquisa, pôde perceber que houve um real aumento da população que se identificava enquanto cabocla na região, segundo os censos oficiais do governo no final do século XIX. Ao contrário do que o governo afirmava oficialmente, os índios ainda se encontravam naqueles territórios, destribalizados, é verdade, mas passando suas histórias oralmente através das gerações e ainda se reconhecendo enquanto indígenas dentro do ambiente familiar, preservando certos costumes e identidade étnica.

Miguel Bartolomé classifica a etnogênese como:

[...] conceito cunhado para dar conta do processo histórico de configuração de coletividades étnicas como resultado de migrações, invasões, conquistas, fissões ou fusões. Entretanto, mais recentemente, passou a ser usado também na análise dos recorrentes processos de emergência social e política dos grupos tradicionalmente submetidos a relações de dominação [...] Já se qualificou de etnogênese o ressurgimento de grupos étnicos considerados extintos, totalmente "miscigenados" ou "definitivamente aculturados" e que, de repente, reaparecem no cenário social, demandando seu reconhecimento e lutando pela obtenção de direitos ou recursos. (BARTOLOMÉ, 2006, p.39-40)

Os Puri enquadram-se nesta última definição de Bartolomé, de ressurgência étnica e que "referem-se ao dinamismo inerente aos agrupamentos étnicos, cujas lógicas sociais revelam uma plasticidade e uma capacidade adaptativa que nem sempre foram reconhecidas pela análise antropológica" ou, ainda, "um processo histórico constante que reflete a dinâmica cultural e política das sociedades anteriores ou exteriores ao desenvolvimento dos Estados nacionais da atualidade" (idem, p.40). Os Puri autodeclarados somam 675 pessoas no Rio de Janeiro, segundo o censo IBGE de 2010. Vivem atualmente em contexto 
urbano na capital, onde inicialmente surgiu este movimento em 2013, em cidades no interior do estado fluminense e no interior de Minas Gerais.

Os Guarani, por serem o povo indígena mais numeroso do estado, foram presença marcante, especialmente pelo fato da curadora Sandra Benites também pertencer a esta etnia, principal referência de consulta nas pesquisas realizadas e principal articuladora entre eles para inclui-los na exposição, como poderemos observar posteriormente. Atualmente são oito aldeias no estado do Rio de Janeiro, localizadas nos municípios de Paraty, Angra dos Reis e Maricá. Os grupos Guarani que vivem hoje no Brasil são os Mbya, os Kaiowá e os Ñandeva, que se reconhecem como Guarani, compartilham práticas culturais semelhantes, mas com pequenas diferenças na forma de falar seu idioma e praticar sua espiritualidade.

O outro povo que vive aldeado no Rio de Janeiro é o Pataxó. No início de 2017 buscamos os Pataxó que estão instalados atualmente na Costa Verde, na Cachoeira do Iriri (Paraty), num contato através da jornalista Thereza Dantas, que foi convidada pelo professor José Bessa para expor matéria por ela produzida no site "Racismo ambiental"4. Convidada para uma rápida conversa, ela nos inteirou sobre as dificuldades enfrentadas por estes indígenas na região e o contato telefônico de uma das lideranças, Apohinã Pataxó, para que pudéssemos conversar com eles, o que só conseguimos objetivamente durante a última visita realizada a Paraty em trabalho de campo feito naquela região.

O terceiro encontro Dja Guatá Porã, realizado em dezembro, foi o mais intenso, longo e com grande adesão dos indígenas. Vários indígenas Guarani de Paraty, Angra dos Reis e Maricá, os Pataxó, os Puri e representantes de diversas etnias que vivem em contexto urbano deslocaram-se até o museu - alguns deles tendo participado de edições anteriores. Neste encontro afloraram temas como a responsabilidade do museu em assumir um compromisso em mostrar a realidade concreta e objetiva dos povos indígenas na atualidade, sua capacidade de organização e mobilização, a questão da demarcação de terras.

Antes do início, todos os presentes visitaram o andar que receberia a exposição para que pudessem se familiarizar com o museu e visualizar o espaço que iriam ocupar. Na segunda etapa, a mediação de Sandra Benites foi conduzida quase que integralmente em idioma guarani. Uma experiência única para os não-indígenas de se colocarem no lugar do índio de "estrangeiros em sua própria terra", já que os Guarani têm como segundo idioma o português e compreendem perfeitamente o que falamos, mas nós não tínhamos capacidade de compreender absolutamente nada abordado pelos indígenas em seu idioma materno, experimentando um pouco o sentimento de saber como é ter a sua língua descartada. Aliás, as línguas indígenas com falantes no Rio de Janeiro constituíram um tópico importante da mostra.

\footnotetext{
${ }^{4}$ Notícia disponível em "http://racismoambiental.net.br/2016/07/28/caminhantes-indigenas/"
} 
Fotografia 1: Jovens indígenas Guarani visitando exposição no MAR

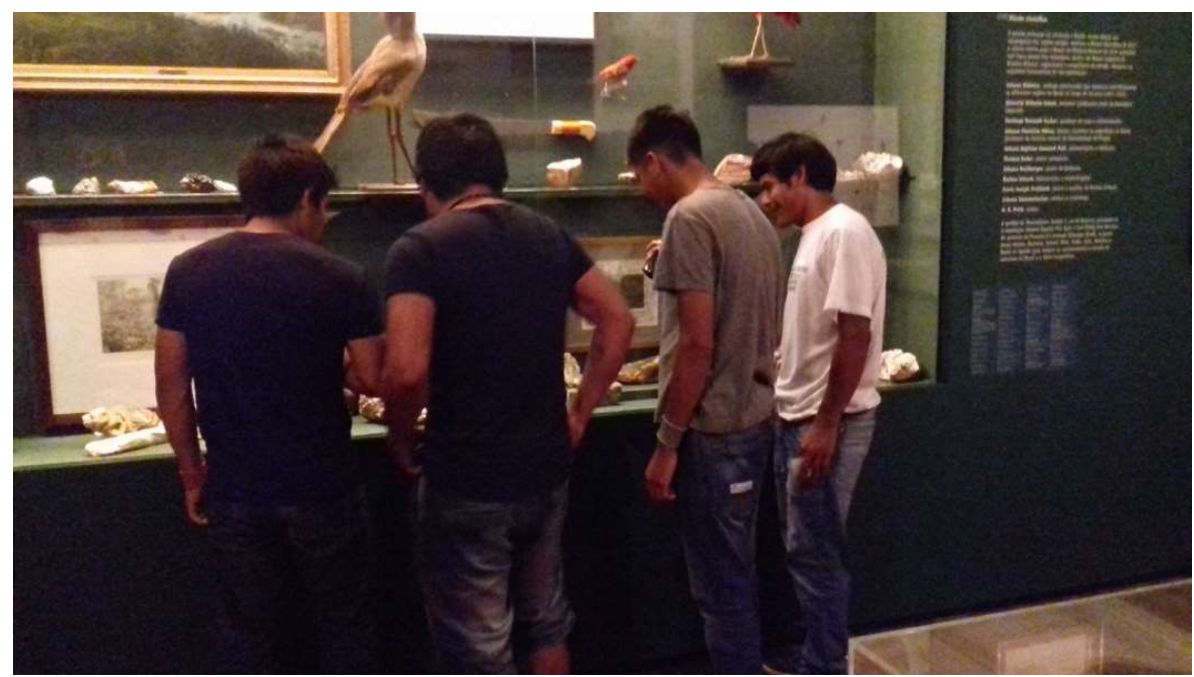

Fonte: Leandro Guedes

Os Guarani questionaram bastante a proposta da exposição, pois estavam preocupados, entre outras coisas, com a capacidade deles de produzir material suficiente, até pela falta de autonomia territorial de algumas aldeias - ainda em processo de demarcação - e por uma desconfiança sobre o que esperar do museu. Para alguns, o "branco" não é capaz de entender a cultura indígena. O papel do museu e sua utilidade foram constantemente questionados pelos indígenas nestes encontros; duvidam de sua validade, pois alguns acreditam que ele só serve para reforçar estereótipos preconceituosos e que abordam somente o indígena do passado, em uma imagem congelada de 500 anos atrás. Mais importante foi a fala de algumas lideranças e jovens Guarani questionando se o museu realmente tem validade para que eles sejam mais respeitados, pois suas identidades estavam em jogo. Os juruá como denominam quem não é índio - respeitariam suas danças, sua reza, sua língua, seu nhanderekó?

Logo perceberam que a exposição do MAR talvez fosse uma boa oportunidade de levar ao juruá a realidade objetiva deles, contada por eles, da forma que eles julgassem mais conveniente narrar. As lideranças demonstraram compreender o papel educativo do museu para os nãoindígenas e que isto funcionaria apenas se eles, indígenas, concordassem em fazer parte e que a ideia principal ali era que eles produzissem objetos e acervos que os representassem como uma oportunidade de mostrar suas culturas vivas.

A questão econômica, que envolve o artesanato, foi uma problemática longamente debatida, pois para muitos ali a venda de artesanatos seria a exposição, como uma feira de longa duração. Ao final da conversa em guarani, foi possível compreender apenas as poucas palavras em português que não possuem tradução para o idioma guarani que recortavam as frases como: "museu", "preconceito", "escola". Havia alguns tcheramoi presentes, como o Sr. Félix Karai, da aldeia Ara Owy Re de Itaipuaçu, um ancião respeitado por todos, assim como outras lideranças como Algemiro e Miguel, que assumem publicamente 0 
sentimento geral de desconfiança com os brancos. A fala do sr. Félix sintetiza as relações históricas e contemporâneas estabelecidas entre indígenas e não-indígenas: "antes o juruá matava só com arma. Hoje tá matando até com papel".

Fotografia 2: Senhor Félix Karaí em reunião de aldeias Guarani do Rio de Janeiro no MAR

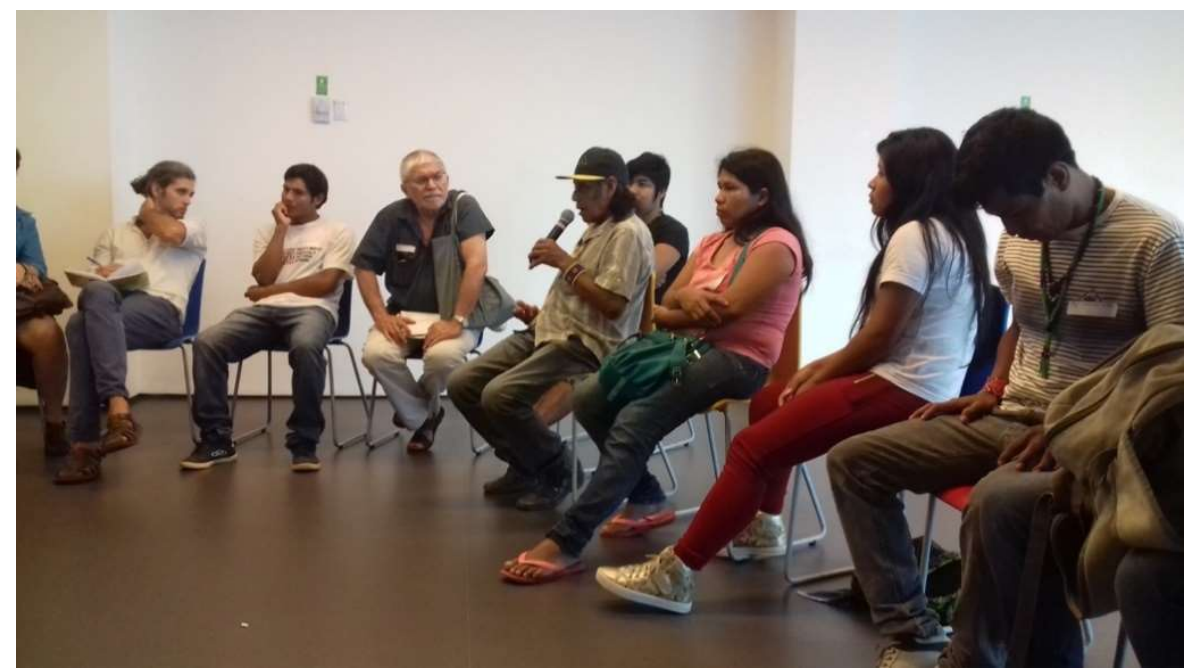

Fonte: Leandro Guedes

Os mais jovens foram os que se mostraram mais entusiasmados com a ideia de participarem da exposição, assim que compreenderam o propósito e viram uma boa oportunidade de dar visibilidade ao trabalho que já produziam e de contarem as histórias de seu próprio povo. As ressalvas foram feitas por Alexandro: "É a nossa cultura que está em jogo. Será que vão nos respeitar mais?", "Qual a opinião dos mais velhos sobre o que vai ser mostrado?". Alexandro possui conhecimento no campo audiovisual, sabe utilizar câmeras, editar, mas lhe falta o equipamento, muito caro para poder dar continuidade ao seu trabalho. Faz parte de um coletivo que produz materiais sobre as narrativas míticas guarani contadas pelos anciãos. Esta realidade também é compartilhada por outros, como Miguel Verá-Mirim, que nos recebeu em Maricá e que também possui alguns filmes sobre a cultura material e imaterial guarani produzidos por ele, aos quais tivemos a oportunidade de assistir durante trabalho de campo realizado na aldeia de Rio Pequeno. Ao fim da conversa, os Guarani combinaram conversar primeiro entre si e nos convidaram para uma conversa geral na aldeia.

\section{A visita às aldeias}

Entre o segundo e o terceiro "Dja Guata Porã" foram realizadas visitas da equipe de pesquisa e curadoria às aldeias guarani de Sapukai 
em Angra dos Reis, Itaxi e Paraty-Mirim em Paraty, Ka'aguy Ovy Porã em Maricá e à Aldeia Vertical, onde residem em torno de 17 etnias do grupo da AIAM, incluindo alguns Puri. O propósito destas visitas era de realizar aproximações com os índios apresentando a proposta do MAR em realizar uma exposição sobre a presença indígena no estado do Rio de Janeiro, sob uma ótica contemporânea, em que eles próprios seriam responsáveis por decidir o que gostariam que estivesse presente em seus respectivos núcleos e se sentissem representados. Já havíamos visitado anteriormente a Aldeia Maracanã em outra oportunidade na qual o cacique Carlos Tukano nos apresentou a trajetória e luta da AIAM.

Tanto na Aldeia Maracanã, quanto nas aldeias Guarani que visitamos a questão econômica não foi ignorada pelos indígenas. Os Guarani de Paraty-Mirim e Sapukai não compreenderam inicialmente a proposta da exposição, uma vez que para eles museus são lugares estranhos que não dizem nada que lhes interesse. A compreensão inicial foi de que seria uma feira de artesanatos que iria contar com a participação deles, onde pudessem vender seus produtos. A fim de resolver este novo desafio, além das longas conversas que se estabeleceram nestas visitas, curadores e pesquisadores procuravam apresentar experiências nas quais os indígenas tiveram a oportunidade de construir suas próprias narrativas. A validade destas experiências e do Museu como uma possível ferramenta de divulgação de suas causas, de suas formas de ser e das reafirmações identitárias, constituía uma garantia de que haveria o esforço para destinar os espaços a estes grupos dentro da exposição seguindo esta mesma lógica, cujo comprometimento está alinhado com discussões museológicas atuais na articulação de contextos culturais diversos, possibilitando a geração de autonarrativas. Outra estratégia de convencimento foi o fato de no MAR passarem por volta de 400 crianças diariamente que fazem parte do seu projeto educativo, em visitas escolares mediadas.

A curadora Sandra Benites já havia conversado com a equipe sobre o fato de os Guarani serem muito cautelosos e desconfiados em suas negociações com os juruá. Adquirir a confiança de um não-indígena por um Guarani é uma tarefa que requer trabalho, paciência e principalmente, honestidade em suas intenções, de modo que eles a percebam. Inegável que a mediação da curadora guarani entre seu povo e também junto à Aldeia Vertical, onde reside atualmente, foi um facilitador nessas negociações iniciais.

Em Maricá, o sentimento de desconfiança e estranhamento também esteve presente, mas a recepção de uma das lideranças da aldeia, Miguel Verá-Mirim, e da professora Jurema foram um pouco diferentes. Neste caso, contamos com dois facilitadores: a parente Sandra e o professor José Bessa, ex-professor e amigo do então cacique Darci Tupã e de outros Guarani que ali residem. Miguel nos contou um pouco de sua história pessoal, sua caminhada até Maricá, a trágica ocupação em Camboinhas, a situação da aldeia frente à FUNAl e ao poder público. Ele nos guiou por um passeio pela aldeia, nos mostrou a cozinha comunitária, a horta onde plantam o milho (e nos deu um milho guarani de presente) e o sinal de que nos via como amigos e aliados: convidou-nos todos a conhecer a Opy 
da aldeia, a Casa de Reza Guarani, local sagrado e de cura onde adentramos respeitosamente.

A última visita aos Guarani ocorreu em janeiro de 2017 em um encontro de dois dias na aldeia de Rio Pequeno, visando definir quais acervos os Guarani gostariam de produzir para se verem representados na exposição. Iniciativas idênticas foram realizadas com os Puri e os Pataxó.

O encontro de Rio Pequeno durou dois dias, tendo início de manhã e se estendendo até o final da tarde. Muito das conversas realizadas no "Dja Guata Porã" foram repetidas para os moradores da aldeia e outros Guarani que não puderam participar, incluindo o cacique de Rio Pequeno, Seu Demécio. A principal articuladora do encontro, Clarissa Diniz, organizou, com anuência dos Guarani, grupos de discussão entre eles para que decidissem o que seria de grande relevância para estar presente na mostra. A importância dos tcheramoi, da Opy e da caminhada Guarani foram temas bastante abordados; assim como a produção dos bancos em formas de animais esculpidos em madeira, o processo ritual da pintura corporal Guarani, a plantação do milho, a fabricação e a dimensão espiritual do petenguá, cachimbo utilizado somente em reuniões consideradas importantes e em rituais, e o território guarani, o tekohã, fundamental para eles poderem viver o teko, o "bem viver" tradicional guarani.

Fotografia 3: Encontro Guarani em Rio Pequeno, Paraty (RJ)

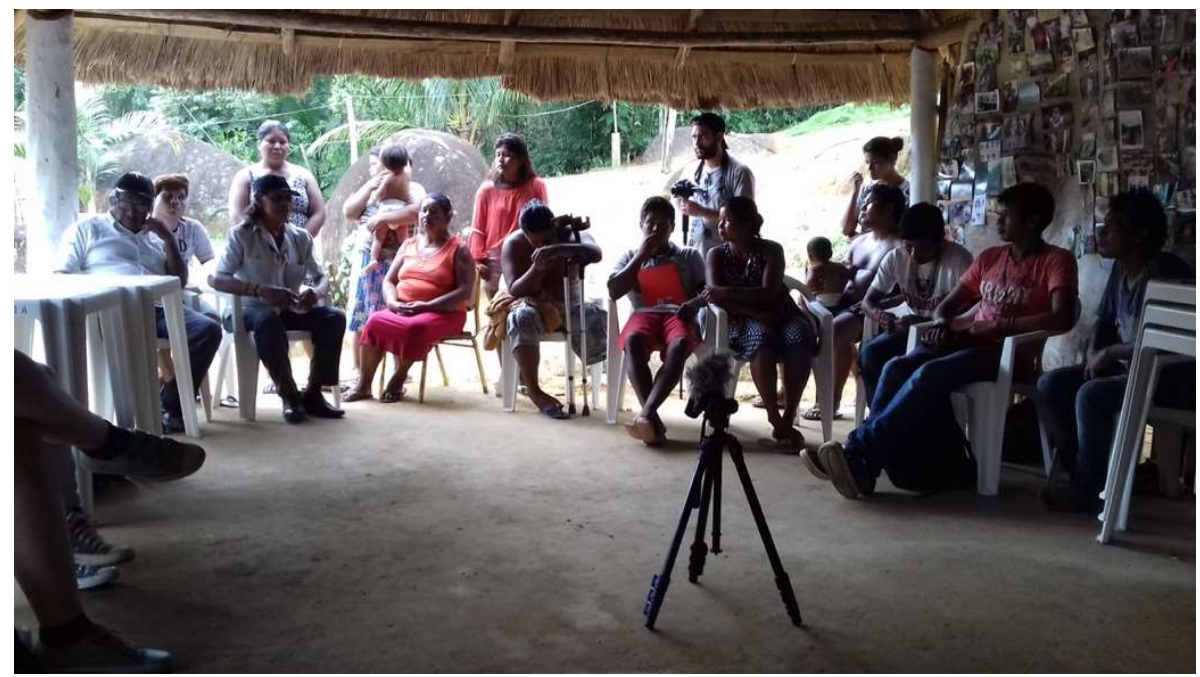

Fonte: Leandro Guedes

Conforme as conversas avançaram os Guarani fumavam seus petenguá, um bom sinal de que as coisas iam bem para eles, que foram propondo não somente o que gostariam que estivesse exposto, mas através de quais meios. Ficou decidido que haveria fotografias, vídeos e objetos produzidos por eles, e a divisão de trabalho seria realizada entre os próprios índios. Coube a Clarissa Diniz explicar que todos os objetos, fotografias e vídeos seriam pagos, e que o Museu providenciaria suporte a apoio técnicos, como equipamento e pessoal, caso fosse necessário, para as produções fotográfica e videográfica. 
Durante o primeiro dia na aldeia de Rio Pequeno, o professor José Bessa contatou um Pataxó casado com uma guarani de Rio Pequeno, presente à reunião e após uma primeira conversa de aproximação, em que se explicou o intuito de nossa presença ali na aldeia e da exposição, nos dirigimos à aldeia Pataxi Uy Tanari, às margens da BR-101, cerca de 20 minutos de carro de onde nos encontrávamos. O professor foi bem recebido na aldeia e nos abriu a possibilidade de visitá-los em nosso último dia na cidade. Fomos recebidos pelos Pataxó que usavam pinturas corporais e adornos. Antes do início da reunião nos deram boas-vindas e performaram a dança do Awê, para ao mesmo tempo nos saudar e garantir benção e proteção.

A abordagem foi a mesma: apresentação do discurso da visibilidade permitida pelo museu através da exposição e seu propósito pela curadora Clarissa Diniz, reforçando o caráter participativo, educativo e de combate ao preconceito a que nos propusemos, demonstrando realidades indígenas contemporâneas e garantindo espaços de autonarrativas para estender-Ihes o convite, prontamente atendido, de nos visitar em fevereiro a fim de darmos prosseguimento às conversas relacionadas à participação deles na exposição.

Os Pataxó da Costa Verde na realidade são Pataxó Hã-Hã-Hãe, que abarcam naquela realidade as etnias Pataxó e Tupinambá. Segundo eles, instalaram-se naquela região por orientação espiritual, fugindo do massacre a que seu povo é submetido no sul da Bahia. Muitos ali são da terra indígena Caramuru-Paraguaçu, delimitada em 1937 pelo então SPI. Instalaram-se primeiro em Angra dos Reis no bairro do Perequê por onde ficaram por quase 10 anos e viram-se novamente obrigados a migrar por causa da violência, desta vez a urbana. A questão territorial para os Pataxó foi o tema mais importante. Instalaram-se na região da Cachoeira do Iriri e sofrem pressões para abandonar a área, recorrendo tanto ao Ministério Público quanto à FUNAI para que a terra possa ser demarcada. O território atual os agrada por ser numa aprazível zona de mata, próximo de água corrente e limpa e pela facilidade de deslocamento para atendimento médico dos mais velhos e para os mais jovens, em idade escolar, poderem estudar. Atualmente são 17 famílias que vivem na aldeia. 
Fotografia 4: Encontro com os Pataxó na aldeia em Iriri, Paraty (RJ)

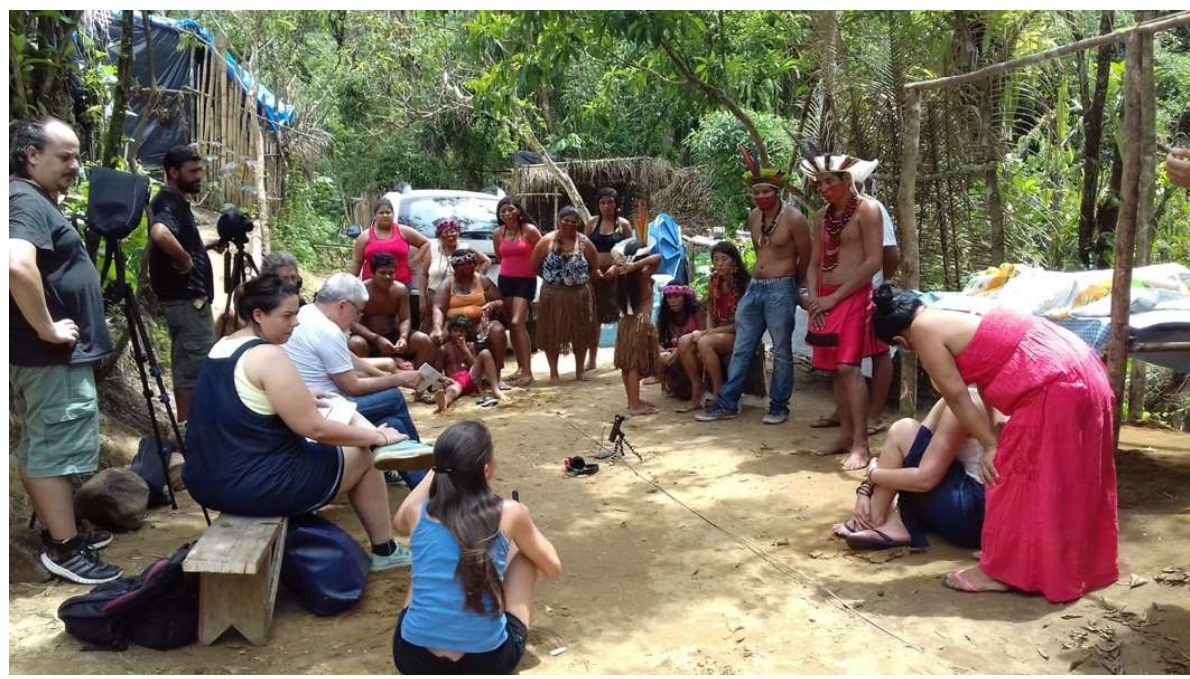

Fonte: Mariane Vieira

Durante todo o processo dos encontros "Dja Guata Porã" e de todas as reuniões que se seguiram, a exposição procurou tomar como base o material coletado por pesquisadores e curadores durante os encontros abertos, nas reuniões e trabalhos de campo, para preparar o espaço da exposição e para fornecer o apoio necessário, logístico e financeiro para a realização das atividades solicitadas e propostas pelos indígenas. Em caso de não haver consenso entre equipe e indígenas, prevalecia a decisão deles.

Um impasse nos foi colocado durante a visita à aldeia de Rio Pequeno, em Paraty, no encontro que serviu para determinar de que maneira - e o quê - os guarani gostariam de apresentar na exposição. Em dado momento, partiu das lideranças de Rio Pequeno o pedido para que fosse construída uma casa de cultura que, para fins práticos, de acordo com cacique Demécio, funcionaria tanto para recepcionar os visitantes da aldeia quanto para venderem o artesanato produzido por eles, assim como estocar materiais e sua produção. Foi um pedido inesperado para a equipe de curadores e pesquisadores, e que foi sendo debatido durante nossa estadia.

As demais aldeias Guarani se limitaram a discorrer sobre o que consideravam fundamental que estivesse presente e que gostariam de produzir. Havia a real possibilidade de Rio Pequeno não participar da exposição caso seu pedido não fosse aceito e a conversa entre a curadora Clarissa Diniz com a aldeia foi determinante. Primeiro deixando claro que haveria um pró-labore, e que nenhum deles produziria nada de graça, estendendo aos grupos indígenas a forma de trabalhar do MAR em qualquer outra exposição de arte do Museu e segundo, que o MAR não tem recursos financeiros disponíveis para arcar com uma obra deste porte e que também era vedado este tipo de ação pela legislação vigente. A questão financeira enfrentada nas aldeias também surgiu com os indígenas na cidade. A principal fonte de renda é a venda de artesanato, como abordado anteriormente, mas enfrentam muitas dificuldades para conseguir trabalhar, como custear o deslocamento e conseguir espaços 
em pontos de vendas, como feiras populares ou espaços fixos em determinado local da cidade.

\section{A exposição “Dja Guata Porã: Rio de Janeiro Indígena”}

Inaugurada em 16 de maio de 2017, "Dja Guata Porã: Rio de Janeiro Indígena" ficou exposta até 25 de março de 2018 no MAR.

A questão indígena é um tema bastante amplo e complexo. Permite múltiplas abordagens museológicas e por este motivo há o desafio contínuo no cuidado em definir quais temas serão retratados e quais recortes devem ser realizados, de modo a não incorrer em imprecisões históricas ou narrativas etnocêntricas. Este desafio é ainda maior em uma exposição polifônica, construída coletivamente e interculturalmente. As exposições são a principal ou mais específica forma de comunicação de um museu (CURY, 2005), e tem por objetivo criar as condições para que o público tenha uma experiência única de apreciação.

A exposição seguiu um formato inédito no MAR, desde a sua concepção, enquanto resultado de pensamentos de vários atores, saberes e visões de mundo, até sua execução museográfica, composta por quatro núcleos principais divididos entre os Guarani, Pataxó, Puri e indígenas em contexto urbano. Participaram da concepção do projeto a arquiteta Cristina Gouvêa e o arquiteto Marcus Vinícius Santos.

A exposição começava na rampa de acesso do prédio da Escola do Olhar do MAR para o pavilhão de exposições. Uma montagem sonora com gravações de diversos indígenas saudando os visitantes em suas línguas maternas, pretendia mostrar que o Rio de Janeiro não é monolíngue como se faz crer, e sim uma verdadeira "babel" de diferentes idiomas que produzem conhecimento, cantos, literatura, narrativas míticas, poesia. Esta passarela, montada como espaço de afirmação e resistência de identidades étnica, contou com a participação decisiva da Rádio Yandé ("Nós", em tupi), uma webrádio criada em 2013 no Rio de Janeiro, por Anapuáka Muniz Tupinambá, gestor em marketing, Denilson Baniwa, artista plástico e designer, e Renata Tupinambá, e que hoje conta com 180 colaboradores e correspondentes numa programação 24 horas com música, entrevistas, depoimentos, poesias e programas informativos, que podem ser acessados por aplicativo para celular. Eles usam a tecnologia como uma "flecha digital" disparada contra os preconceitos veiculados pela grande mídia. Os depoimentos ouvidos na instalação foram recolhidos por Anapuáka Tupinambá e Denilson Baniwa, este último responsável pelo desenho da linha do tempo juntamente com Priscilla Gonzaga. 
Fotografia 5: - Instalação sonora da rampa de acesso ao pavilhão expositivo do MAR

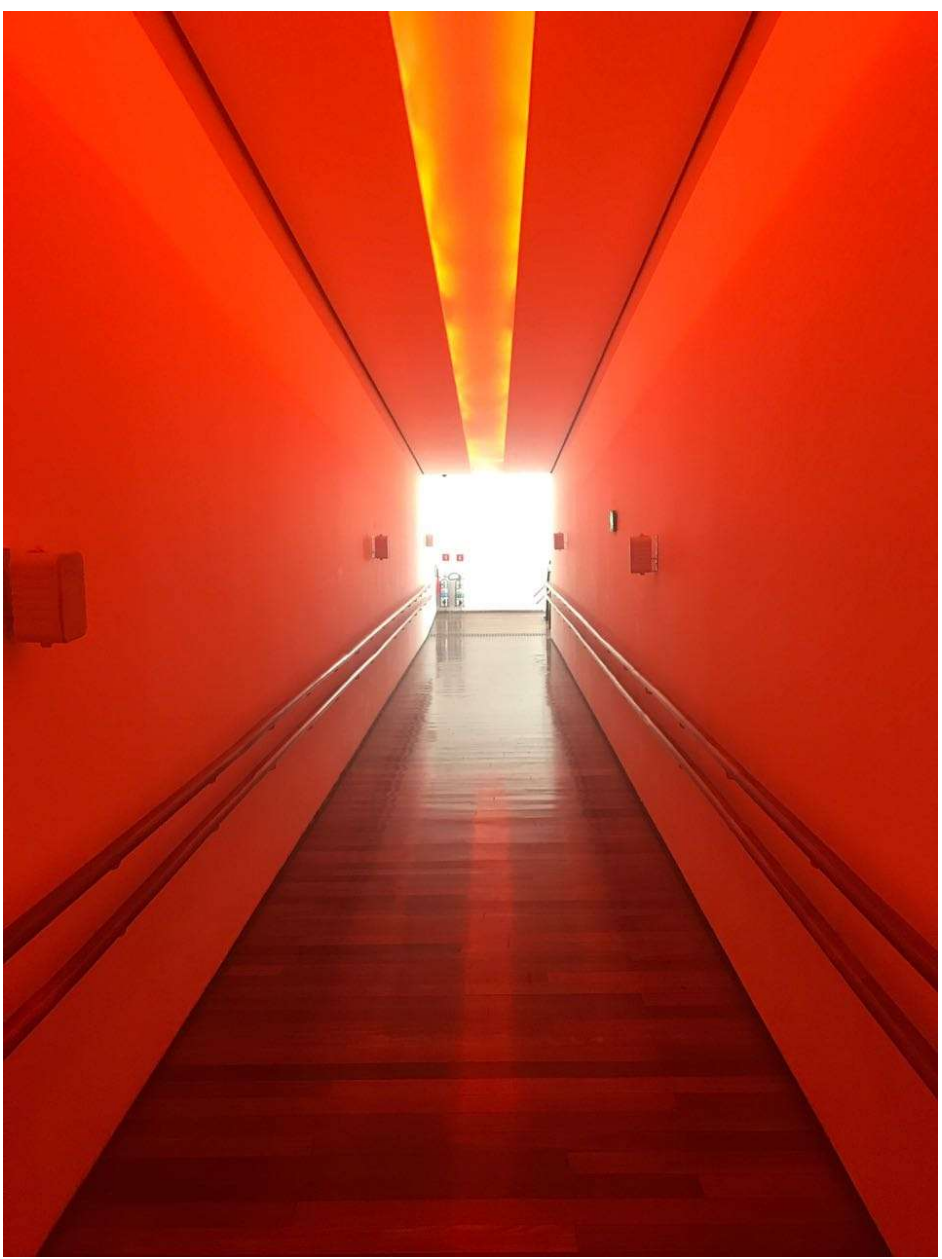

Fonte: Leandro Guedes

Ao adentrar a sala de exposição, o visitante poderia circular livremente pelo espaço, virando à direita ou à esquerda. A sala de exposições do MAR é em formato retangular, dividida por uma pequena área de serviço, localizada à frente da saída da rampa onde ficam bebedouros e banheiros, de modo que os acessos entre as salas são em corredores paralelos nos extremos das salas, ou seja, um logo após a saída da rampa de acesso, outro na parede do lado oposto. Apesar da liberdade dada ao visitante, foi escolhido um ponto de partida da exposição, virando à esquerda. Desta maneira, cada sala ficou com dois núcleos principais; à esquerda os Pataxó e Puri, à direita os Guarani e os indígenas em contexto urbano. Em ambas as salas também foram instaladas "estações", pequenos nichos no espaço expositivo com a proposta de enfatizar temas específicos considerados importantes nos encontros realizados com os indígenas: comércio, natureza, educação, arte e mulheres. A curadoria das estações foi realizada por um indígena específico, que possuía especialização acadêmica ou maior vivência relacionada à temática.

A conformação do prédio sugere uma situação de linearidade na visita à exposição. Porém, à exceção da linha do tempo, que pressupõe um imperativo cronológico dos acontecimentos, os núcleos principais 
foram pensados de forma que pudessem ser vistos independentemente, mas sem perder sua conexão com o todo, não dependendo da linearidade proposta. No que consideramos o início da exposição, ou seja, à esquerda da entrada do pavilhão expositivo, dando boas-vindas ao público e apresentando a mostra, há o texto curatorial e um vídeo de pouco mais de oito minutos do processo de construção de "Dja Guata Porã: Rio de Janeiro Indígena"s. O texto curatorial foi apresentado em versões em português, inglês e guarani. A escolha pelo guarani foi feita pelo fato de serem o povo mais populoso aldeado do estado e por ter um grande número de falantes em todo o território nacional. Também foi sugerido o uso do guarani nas legendas da exposição, o que não foi possível de ser realizado em razão de normas estipuladas pelo museu que preveem somente o português e o inglês como idiomas "oficiais" a constarem nas exposições.

A linha do tempo, no formato de uma grande cobra-canoa, percorre as paredes em formato de "u". Nesta cobra-canoa, símbolo presente em narrativas míticas de povos indígenas amazônicos, foram entrecruzadas perspectivas e narrativas ocidentais e indígenas (como os mitos da avó do mundo do povo Desana - que dá início à linha do tempo -, o demiurgo "Omama" do povo Yanomami e o "Aukê" dos Krahô, por exemplo). Na busca por outras temporalidades, a equipe curatorial decidiu segmentar a linha do tempo inspirada em uma narrativa dos Huni Kuin do Acre, que dividiram sua história em cinco períodos: Tempo das Malocas, Tempo das Correrias, Tempo do Cativeiro, Tempo dos Direitos e Tempo do Governo dos Índios. Curadores e pesquisadores, adaptaram essa classificação, resumida em quatro períodos: Tempo da Autonomia, Tempo da Invasão, Tempo da Usurpação e Tempo das Retomadas. Na cobra-canoa, grafismos e mitos indígenas, vídeos, textos, documentos e objetos arqueológicos buscam dar conta de uma história extensa e complexa de mais de 500 anos de conflitos com invasores e da resistência indígena.

\footnotetext{
${ }^{5} \mathrm{O}$ video está disponível na plataforma YouTube no canal do MAR: https://www.youtube.com/watch?v=HJcxYBLiDUE
} 
Fotografia 6: Linha do tempo Cobra-canoa

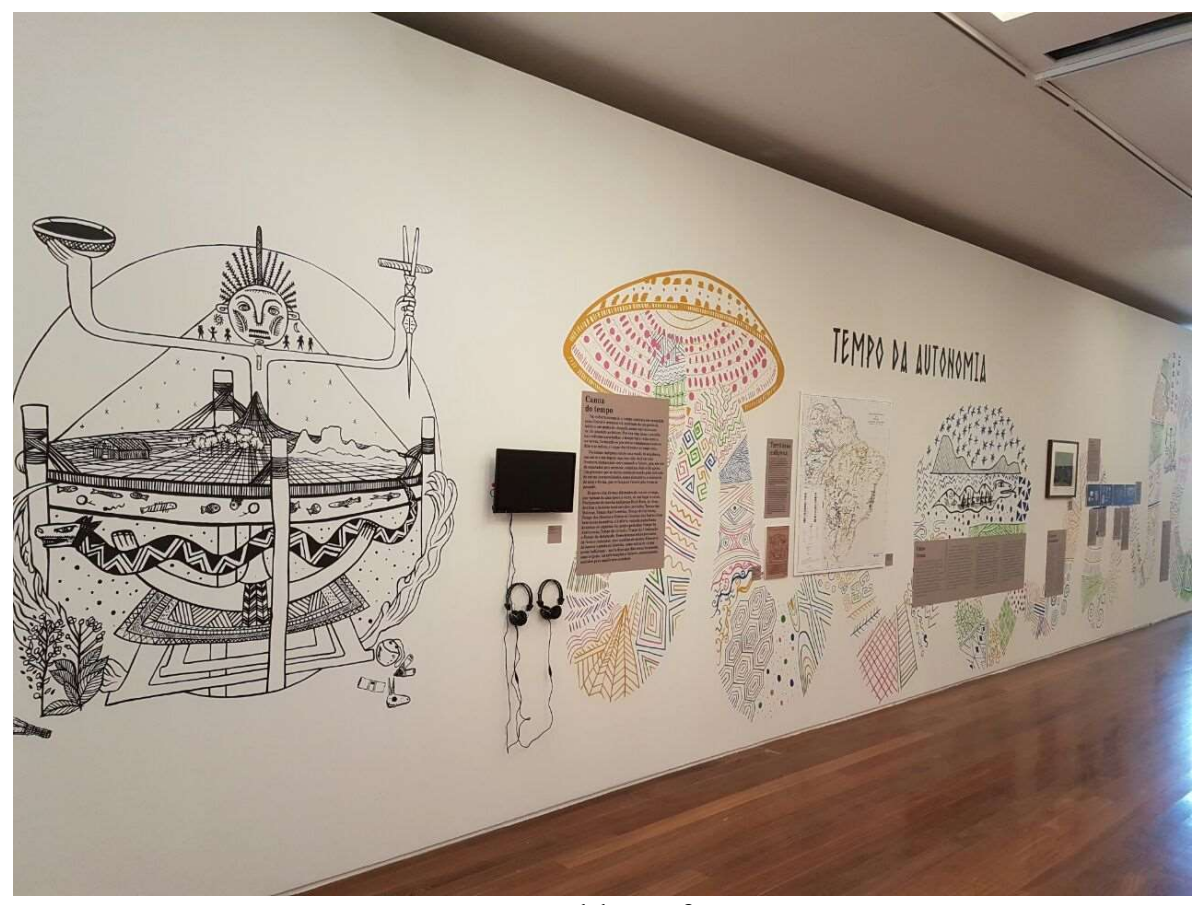

Fonte: Pablo Lafuente

No núcleo Pataxó, é narrada, em vídeo, pelos Pataxó Hã-Hã-Hãe da aldeia de Iriri a diáspora deste grupo do sul da Bahia até o local atual que ocupam e sua busca por demarcação e reconhecimento daquela terra. Também escolheram expor objetos etnográficos produzidos pelos próprios, como armas e armadilhas de caça, que servem tanto para venda, como para uso cotidiano. No núcleo Puri, iconografias e histórias contemporâneas e do período colonial se entrecruzam com alguns poucos objetos e recursos artísticos e educativos como o tapete produzido por Carmel Puri, que tem por objetivo contar a história do povo Puri, que habitava a região fluminense do Vale do Paraíba e da Zona da Mata mineira. Esta história é contada em vídeo pela criadora da obra (VIEIRA, 2019). Neste espaço ainda foi criado um projeto artístico de uma Sapucaia, árvore tida como sagrada pelos Puri, adaptando uma pilastra, transformando-a em um tronco. Contornando a pilastra, uma espiral com frases extraídas do vocabulário puri, criado por Marcelo Lemos, e publicações produzida pelos Puri foram disponibilizadas para leitura e apreciação dos visitantes. 
Fotografia 7: Núcleo Pataxó

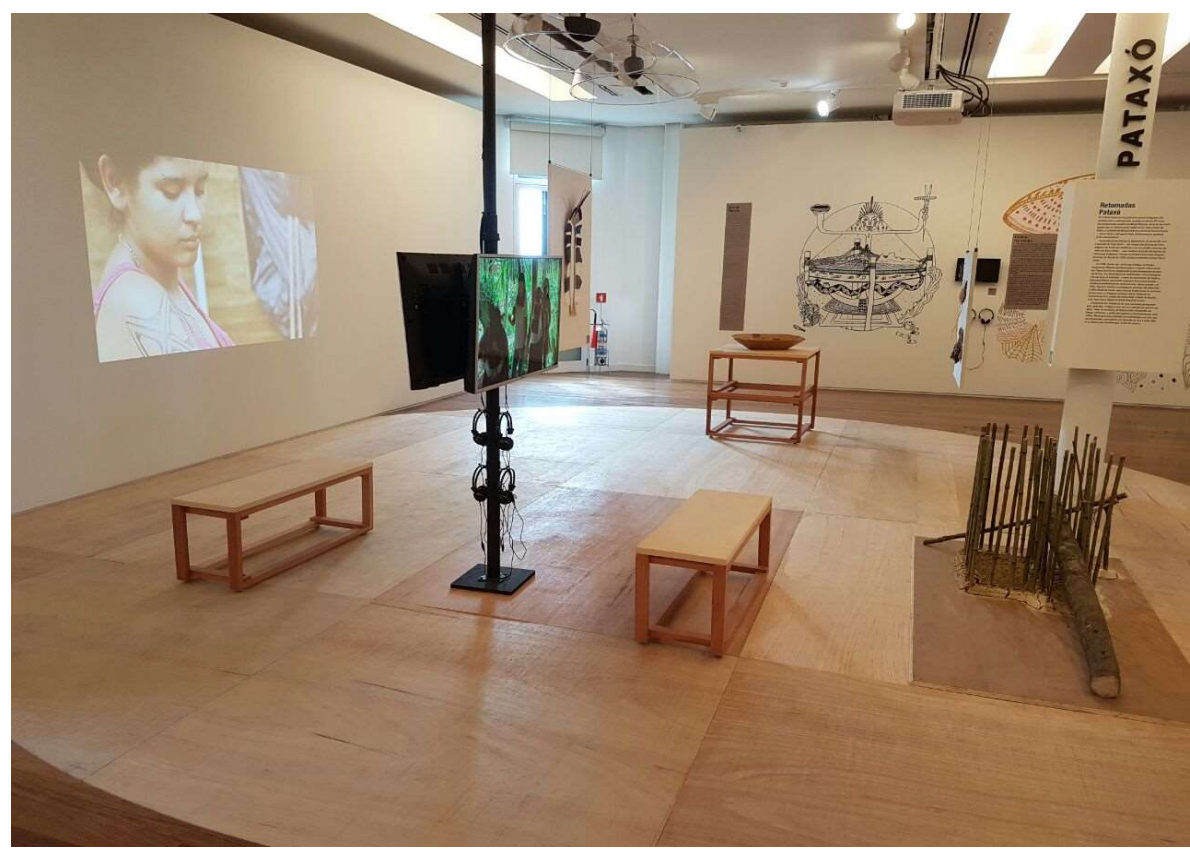

Fonte: Pablo Lafuente

Fotografia 8: Núcleo Puri

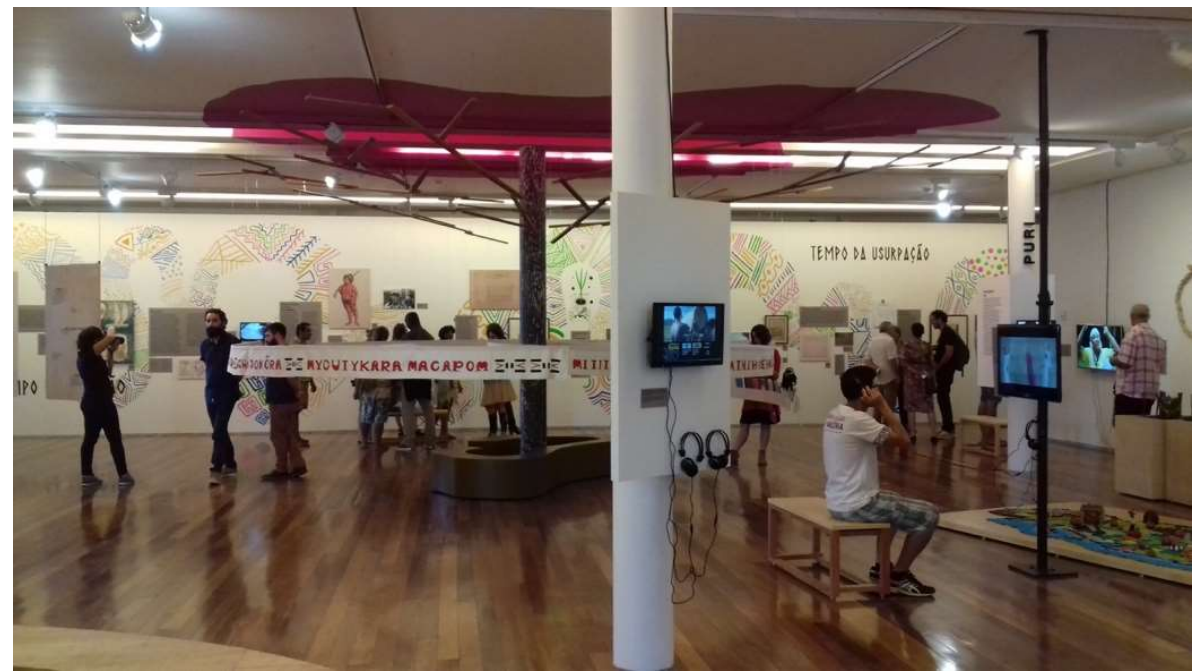

Fonte: Leandro Guedes

O núcleo de indígenas em contexto urbano, por sua vez, procurou abordar a complexa temática de relações entre indígenas e não-indígenas na cidade. Frequentemente belicosa e colocando o indígena sempre em posição desfavorável nas disputas com o não-indígena, o foco foi sobre as narrativas de resistência da "Aldeia Maracanã", dividida e representada principalmente por dois movimentos urbanos intitulados Associação Indígena Aldeia Maracanã (AIAM), liderada por Carlos Tukano, e pelo movimento Aldeia Rexiste, liderado por José Urutau Guajajara. Neste espaço foram dispostas fotos fornecidas por alguns indígenas que participaram desde o primeiro momento da ocupação do prédio, em 2006, como Afonso Apurinã, os próprios Carlos Tukano e José Guajajara, 
dentre outros, em um grande mural instalado na parede. Produções videográficas abordaram a ocupação do antigo prédio do Museu do Índio no bairro Maracanã e a violenta expulsão dos indígenas perpetrada por agentes do Estado. Também constavam uma maquete do projeto de transformar aquele espaço em universidade. A busca de uma forma própria de "urbanidade cultural", que seja ao mesmo tempo movimento de resistência e construção de espaços de convivência e diálogo, perpassa a noção destes indígenas de não perderem suas identidades étnicas, inventando um "novo modo de ser indígena". Neste sentido, a instalação "Oca do Futuro", de Salissa Rosa, moradora da Aldeia Vertical (onde residem os membros da AIAM), filha de indígena, retrata um pequeno cubículo, disposta de uma rede pendurada e um álbum de fotos da Aldeia Maracanã ao lado, convidando ao visitante a experienciar a dificuldade de reproduzir os costumes tradicionais dentro do condomínio onde está inserida a aldeia, e a sensação de prisão e confinamento evocadas ao adentrar em um espaço de muitas portas e paredes, ao contrário da vida livre na aldeia, em contato direto com a natureza, repleta de espaço.

A proposta do núcleo Guarani foi a de apresentar ao público visitante sua história e seus costumes, com variedade de suportes expositivos, como vídeos, instalações sonoras, fotografias e objetos etnográficos, como os famosos bancos guarani. Como demonstra a museóloga e pesquisadora de "Dja Guata Porã", Mariane Vieira

A participação de cineastas guarani é uma característica desse núcleo. O vídeo Ara Ovy ("O que é ser índio?", 2017), com roteiro de Jeovane Karai Tataendy e dirigido por Miguel Rogério Verá Mirim Caceres, mostra as diferenças entre os indígenas e não indígenas, explorando ideias centrais para a formação da pessoa guarani (...). Em Jeguata Porãrã ("Caminhada boa", 2017), também sob a direção de Verá Mirim Caceres, a narrativa se estrutura na caminhada do pajé Féliz Karaí até seu estabelecimento no distrito de Itaipuaçu, em Maricá. (...) a Associação Comunitária Indígena de Bracuí (ACIBRA) produziu o vídeo Ovãe ma Jakaxa ("Chegou a época de caça", 2017). Algemiro da Silva aparece explicando aspectos da técnica de caça (...). Já a aldeia Itaxim abordou a temática da educação e do mito do nascimento do sol e da lua através dos vídeos Jepotá Rekó ("Conselhos para a vida", 2017) e Kuaray ha'egui Jaxy ("Nascimento do Sol e da Lua", 2017). Alberto Álvares, junto aos indígenas da aldeia Rio Pequeno, filmou Djeroky Mara'e'yn (Nhanderu, "Deus", 2017), em que exibe danças e cânticos usados em rituais pelos Guarani, destacando o aspecto feminino e masculino em que se dividem, além da presença de cenas de jogos e brincadeiras. (VIEIRA, 2019, p. 248249) 
Fotografia 9: Núcleo de indígenas em contexto urbano

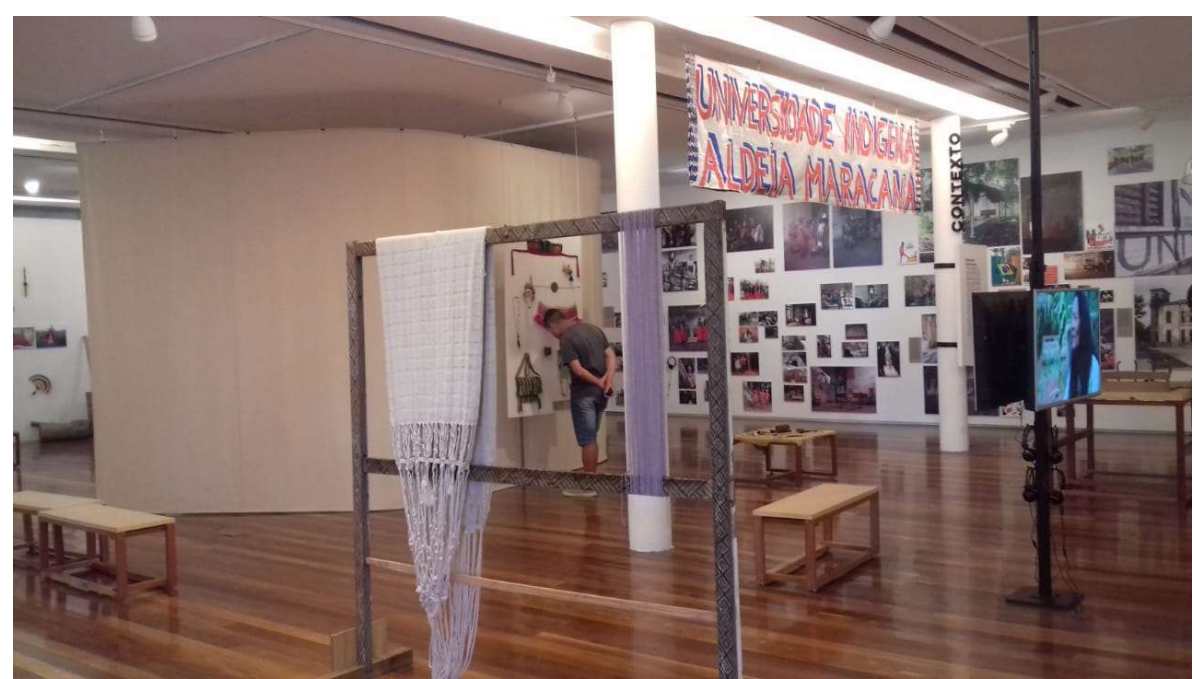

Fonte: Leandro Guedes

Fotografia 10: Núcleo Guarani

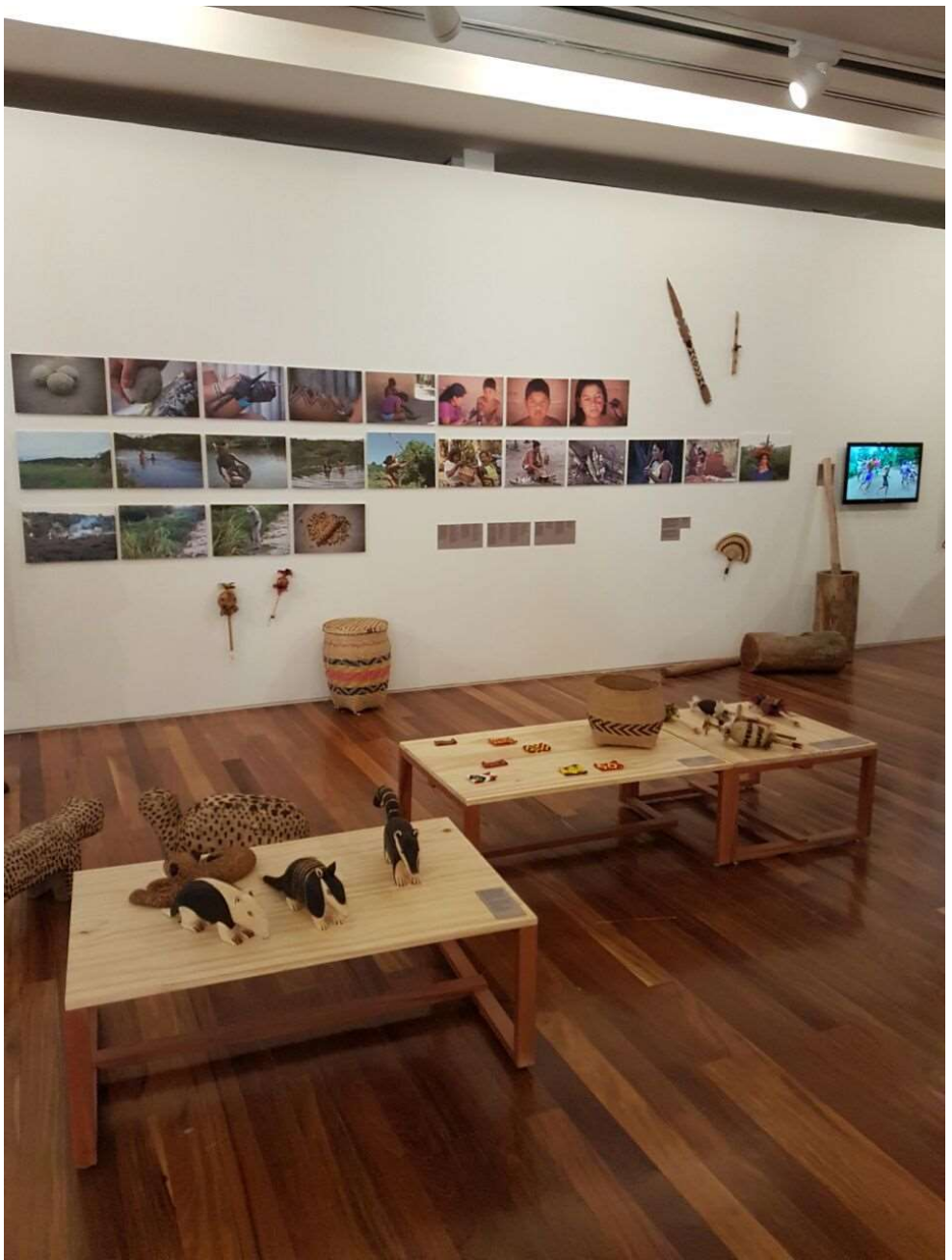

Fonte: Pablo Lafuente 


\section{Considerações finais}

Observamos nos processos de construção de "Dja Guata Porã: Rio de Janeiro Indígena" o exercício decolonial museológico e curatorial, onde o museu não serve apenas como o reprodutor de discursos e práticas colonizatórias, necessariamente hierarquizantes. $O$ esforço em estabelecer o diálogo e ação com os povos indígenas entre os profissionais do museu, provavelmente foi uma oportunidade única do MAR em modificar suas políticas de pensar e executar exposições. Não é possível, entretanto, assegurar que este modelo será seguido no Museu, como ruptura permanente, estabelecendo um novo modus operandi da instituição ao dialogar e incluir novos atores e diferentes perspectivas na criação de linguagens artísticas e museológicas.

Para Edgardo Lander (2005), os museus configuram-se normalmente como instâncias de poder que fazem parte da colonização do "outro", sustentada, entre outros motivos, por uma "naturalização" tanto das relações sociais, quanto da "natureza humana" em uma sociedade capitalista, ocidentalizada, cujas relações com o conhecimento científico produzido só são validadas quando produzidas dentro da lógica civilizatória europeia.

Garantir que os museus se descolonizem, não importando sua tipologia, criando espaços para que os povos indígenas contem suas histórias e sejam reconhecidos como sujeitos e não como objetos, talvez se configure como o maior desafio reflexivo a ser feito para se pensar em exposições etnográficas ou sobre as questões indígenas. No entanto, é impossível ignorar as estruturas e instâncias a que os museus obedecem, que determinarão inequivocamente os limites e possibilidades deste grau de atuação dos povos indígenas em cada museu. 
Espaço Ameríndio

\section{Referências bibliográficas}

ABREU, Regina. Tal Antropologia, qual museu? In: Regina Abreu; Mario de Souza Chagas; Myriam Sepúlveda dos Santos. (Org.). Museus, coleções e patrimônios: narrativas polifônicas. Rio de Janeiro: Garamond Universitária, 2007, p. 138-178.

BARTOLOMÉ, Miguel. As etnogêneses: velhos atores e novos papéis no cenário cultural e político. Mana, v.12, n.1, p. 39-68, 2006.

BESSA FREIRE, José Ribamar. "A descoberta dos museus pelos índios". In: ABREU, Regina; CHAGAS, Mario (Org.) Memória e patrimônio: ensaios contemporâneos. Rio de Janeiro: DP\&A Editora, 2003, p. 219-254.

BESSA FREIRE, José Ribamar; MALHEIROS, Márcia. Aldeamentos indígenas do Rio de Janeiro. Rio de Janeiro: 2a Edição, Eduerj, 2009.

BRULON, Bruno. Museus, patrimônios e experiência criadora: ensaio sobre as bases da Museologia Experimental. Museologia e Patrimônio, v. 1, p. 199-231, 2019.

BRULON, Bruno; GUEDES, Leandro. For Waurá masks in the Indian Museum: a decolonial way to conservation practice and theory. In: MAIRESSE, François; PETERS, Renata. (Ed.). What is the essence of conservation? Materials for a discussion. ICOFOM/ICOM-CC, Paris, 2019, p. 32-38.

CLIFFORD, James. Museologia e contra-história: viagens pela Costa Noroeste dos Estados Unidos. In: ABREU, Regina; CHAGAS, Mario (Org.) Memória e patrimônio: ensaios contemporâneos. Rio de Janeiro: DP\&A Editora, 2003, p. 254-305.

COUTO, Ione. A política institucional e o trabalho curatorial na montagem da exposição "Tempo e Espaço no Amazonas: os Wajãpi”. Questões indígenas e museus: debates e possibilidades. Secretaria da Cultura: ACAM Portinari: Museu de Arqueologia e Etnologia da Universidade de São Paulo, 2012, p. 90-95.

CURY, Marília Xavier. Direitos indígenas no museu - Novos procedimentos para uma nova política: a gestão de acervo em discussão - Introdução. In: (Org.). Direitos indígenas no museu - Novos procedimentos para uma nova política: a gestão de acervo em discussão. Brodowski, São Paulo: ACAM Portinari, Museu de Arqueologia e Etnologia da USP, Secretaria da Cultura do Estado de SP, 2016, p. 12-22.

Exposição: concepção, montagem e avaliação. São Paulo: Annablume, 2005.

GONÇALVES, José Reginaldo. Antropologia dos objetos: coleções, museus e patrimônios. Coleção Museu, memória e cidadania. Rio de Janeiro: 2007.

LANDER, Edgardo. Ciências Sociais: saberes coloniais e eurocêntricos. In: . (Org.) A colonialidade do saber: eurocentrismo e ciências sociais. Perspectivas latinoamericanas. Buenos Aires, CLACSO, 2005, p. 8-23. 
Espaço Ameríndio

LEMOS, Marcelo. O índio virou pó de café?: resistência indígena frente à expansão cafeeira no Vale do Paraíba. Rio de Janeiro: Paco Editorial, 2016.

HALL, Stuart. Cultura e representação. Rio de Janeiro: Editoria PUC-Rio, 2016.

MENSCH, Peter van. O objeto de estudo da Museologia. Rio de Janeiro: UniRio/UGF, 1994.

MORAES, Julia. Museu, informação artística e "poesia das coisas" - A divulgação artística em museus de arte. 2014. 248 f. Tese (Doutorado em Ciência da Informação) PPGCI/IBICT, UFRJ/MCT, Rio de Janeiro, RJ, 2014.

O’DOHERTY, Brian. No interior do Cubo Branco: a ideologia do espaço da arte. São Paulo: Martins Fontes, 2002.

PRATT, Mary Louise. Os Olhos do Império: relatos de viagem e transculturação. São Paulo: Edusc, 1999.

ROCA, Andrea. Acerca dos processos de indigenização dos museus: uma análise comparativa. Mana, v. 21, n. 1, p.123-155, 2015.

SANTOS, Suzy da Silva. Ecomuseus e museus comunitários no Brasil: estudo exploratório de possibilidades museológicas. 2017. 768 f. Dissertação (Mestrado em Museologia) - PPGMus, USP, São Paulo, SP, 2017.

SCHEINER, Tereza. As bases ontológicas do museu e da museologia. ICOFOM Study Series, Paris, n.31, p.126-173, 1999.

STOCKING Jr., George. (ed.). Objects and others: essays on museums and material culture. Madison: University of Wisconsin Press, 1985.

VIDAL, Lux; SILVA, Aracy Lopes da. Antropologia estética: enfoques teóricos e contribuições metodológicas. In: Lux Vidal. (Org.). Grafismo indígena: estudos de antropologia estética. São Paulo: Edusp, 2000, p. 279-294.

VIEIRA, Mariane. Dja Guata Porã: o rio indígena que desaguou no MAR. Horizontes Antropológicos. Porto Alegre, ano 25, n.53, p. 227-256, 2019.

STRÁNSKÝ, Zbynek. Brno: Education in Museology. Brno, Purkine University \& Moravian Museum, 1974.

Recebido em: 09/05/2020 * Aprovado em: 20/05/2020 * Publicado em: 11/09/2020 